\section{Birlesik Dünya Arastırma Cypriot Journal of Educational \\ BD-CENTER \\ Sciences}

Innovasyon ve Yayınalık Merkezi
Volume 16, Issue 6, (2021) 3073-3090

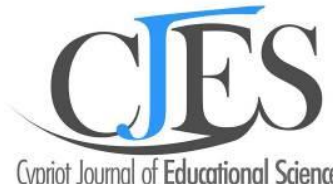

Cypriot Joumal of Educational Sciences

\title{
Character, meaning in life, and well-being of students from teachers' perspective
}

Livia Yuliawati ${ }^{*}$, School of Psychology, Universitas Ciputra Surabaya, Citraland CBD Boulevard, Surabaya 60219, Indonesia. https://orcid.org/0000-0003-4019-042X

Stefani Virlia, School of Psychology, Universitas Ciputra Surabaya, Citraland CBD Boulevard, Surabaya 60219, Indonesia. https://orcid.org/0000-0002-2541-3827

Meilani Sandjaja, School of Psychology, Universitas Ciputra Surabaya, Citraland CBD Boulevard, Surabaya 60219, Indonesia. https://orcid.org/0000-0002-3269-1788

Tasia Puspa Sari, School of Psychology, Universitas Ciputra Surabaya, Citraland CBD Boulevard, Surabaya 60219, Indonesia. https://orcid.org/0000-0002-7674-9814

Mopheta Audiola Dorkas, School of Psychology, Universitas Ciputra Surabaya, Citraland CBD Boulevard, Surabaya 60219, Indonesia. https://orcid.org/0000-0003-3500-3781

Oktufiani Dwi Wulansari, School of Psychology, Universitas Ciputra Surabaya, Citraland CBD Boulevard, Surabaya 60219, Indonesia. https://orcid.org/0000-0002-5165-5547

\section{Suggested Citation:}

Livia Yuliawati, Stefani Virlia, Meilani Sandjaja, Tasia Puspa Sari, Mopheta Audiola Dorkas, \& Oktufiani Dwi Wulansari (2021). Character, meaning in life, and well-being of students from teachers' perspective. Cypriot Journal of Educational Science. 16(6), 3073-3090. https://doi.org/10.18844/cjes.v16i6.6497

Received from August 10, 2021; revised from October 15, 2021; accepted from December 12, 2021.

${ }^{\circ} 2021$ Birlesik Dunya Yenilik Arastirma ve Yayincilik Merkezi. All rights reserved

\begin{abstract}
Previous studies have revealed the benefits of character and meaning in life for individual well-being. However, little research has been conducted on elementary and junior high school teachers who teach students between the ages of 10-15 years (late childhood and early adolescence) in Indonesia. This study aims to explore teachers' perceptions about character, meaning in life, and well-being. Interviews were conducted among 20 teachers. Our findings revealed that according to the teachers, the lessons and assessments in character education are well designed. However, coordination within the school community and with parents as well as specific roles between teachers and parents in building students' character, meaning, and well-being needs to be improved. What teachers understood about meaning in life corresponds with the results of previous studies. Teachers' understanding of well-being concept is still limited. They acknowledged family background, socioeconomic status, popularity, and academic achievement as important factors in students' well-being.
\end{abstract}

Keywords: character; meaning in life; well-being; teachers; children; adolescents

\footnotetext{
*ADDRESS FOR CORRESPONDENCE: Livia, Yuliawati, School of Psychology, Citraland CBD Boulevard, Surabaya 60219 , Indonesia

E-mail address: livia@ciputra.ac.id / Tel.: +62-31-7451699
} 
Livia Yuliawati, Stefani Virlia, Meilani Sandjaja, Tasia Puspa Sari, Mopheta Audiola Dorkas, \& Oktufiani Dwi Wulansari (2021). Character, meaning in life, and well-being of students from teachers' perspective. Cypriot Journal of Educational Science. 16(6), 3073-3090. https://doi.org/10.18844/cjes.v16i6.6497

\section{Introduction}

\subsection{Conceptual Framework}

The word character originates from the Greek word charakter, which means a picture, painting, or sign which resembles the original (Sudrajat, 2011; Author \& Co-Author, 2014). In positive psychology, Peterson \& Seligman (2004) use the concept of character strength, which is an individual characteristic that can develop according to the socio-cultural conditions of the individual. The importance of developing positive character for individuals leads to further studies on how character can be developed through education. In Indonesian context, character education is a priority program since it is intended to equip Indonesia's golden generation in 2045 (Rokhman et al., 2014).

Character development provides positive benefits for students as well as the communities which make up their life context (Lerner, 2018). Park (2004) showed that developing character in students does not only contribute to student well-being, but also prevents symptoms of depression, stress, and problematic behavior. Teachers play an important role in the character development of students (Lestari, 2012). In addition, in character education, teachers also act as designers, managers, implementers, directors, and evaluators of learning (Arifudin, 2015).

The implementation of character education can be effective if there are appropriate strategies and methods for students and relevant with their environment. Character education should be carried out thoroughly by various parties, such as the student's school, family, and surrounding community (Sultoni, 2016). Character education is carried out through intra curricular and extracurricular activities, integrated into subjects, and is part of the culture of each school (Maunah, 2015; Sultoni, 2016). Character education should not only be limited to cognitive level, but also include internalization and practices in the daily life of students. However, it seems that not all schools realize this important point of view. According to Purnomo (2014), this can be the result of several factors: firstly, character education that occurs in schools places more emphasis on providing a lot of information/materials and tends to focus less on the internalization of these characteristics; secondly, the focus on memorization; thirdly, more attention being paid to the materials/content than to the teaching methods in character education; and fourthly teachers not being appropriate role models for students.

Character development in children and adolescents fosters emotional and cognitive social skills could bring further impact on their well-being and meaning in life, for example, by helping them to be sensitive to the needs of others, to engage in prosocial behavior, and to recognize what is right and wrong (Shoshani \& Schwartz, 2018). The characteristics of gratitude and compassion have been found to have a positive relationship with the existence of purpose, which is one of the dimensions of meaning in life (Malin et al., 2017). Prosocial behavior has also been found to be a predictor of meaning in life (Van Tongeren et al., 2017).

As one of humankind's existential questions, studies on meaning in life originate from Frankl \& Frankl (1963) who viewed meaning in life and life purpose as one entity. This research was continued until several researchers proposed that meaning in and purpose in life are constructs that are separate but related to each other (Damon et al., 2003; George \& Park, 2017; McKnight \& Kashdan, 2009). Basic psychological needs satisfaction (Demirbaş-Çelik \& Keklik, 2019) as well as mental well-being were reported as the predictor of meaning in life (Demirbas-Çelik, 2018a). Many previous studies have found that a person's meaning and purpose in life have a positive relationship with resilience (Masten \& Reed, 2002), life 
satisfaction (Steger et al., 2006), greater income (Hill et all., 2016), better health (Cohen et al., 2015; Kim et al., 2013), and well-being (Demirbas-Çelik, 2018b; Howell et al., 2013; Rathi \& Rastogi, 2017).

\subsection{Related Research}

Most previous research on meaning in life was conducted on emerging adults (18-25 years) and adults, including among teachers (Damasio et al., 2013). Unfortunately, very little research was conducted among late childhood and early adolescence. Although children and adolescents do not yet fully realize or actively plan the direction of their lives, meaning and purpose in life originate from their experiences at this age. The involvement of children and adolescents in extracurricular activities and support through the availability of and access to various opportunities enables them to foster directed interests (Bronk, 2012). Children and adolescents' sensitivity to problems in their surrounding environment, fostered by significant others, can inspire them to find meaning in life (Bronk, 2011).

Moreover, Harzer (2016) conducted an overview of several previous studies on character and well-being and found character strength to have a positive relationship with subjective and psychological well-being. Schnitker (2012) also found that patience has a positive relationship with well-being in emerging adults. Therefore, this research is the basis that character, meaning in life and well-being should be further studied in terms of their application in schools.

Teachers and students have a variety of understandings of what it means for an individual to have character (Dwiningrum \& Purbani, 2012). Teachers' perceptions of how character education should be applied and the types of characteristics that can be taught in certain subjects may differ from one another (Sadia, 2013). In addition, perceptions of the roles and responsibilities of each teacher in the implementation of character education taught in schools also differ (Abdia \& Sailan, 2017).

Research in Indonesia has tended to evaluate character education through specific subjects aimed at addressing this need (Faridi, 2014; Isdaryanti et al., 2018; Komalasari \& Saripudin, 2018). Some research has attempted to examine teacher perceptions of character education as a whole (Zurqoni et al., 2018a), but do not include its relevance to meaning in life and well-being of students. Research about teachers' perception has been conducted in senior high schools and vocational high schools (Abdullah et al., 2019; Saputro \& Murdiono, 2020; Zurqoni et al., 2018b). Only a qualitative study about wellbeing has examined what Indonesians discern about wellbeing (Maulana et al., 2018). To our knowledge, few studies have investigated what teachers see about Indonesian students' purpose development.

\subsection{Purpose of the Study}

Though many studies have documented the positive link between character, purpose, and wellbeing, it is interesting to know whether Indonesian teachers also share similar understanding. As the important figure in students' character education, purpose development, and well-being, qualitative research is used since it offers benefits in exploring deeper understanding of teachers about those issues. This is a qualitative study using thematic analysis which offers adaptability to suit research aims (Braun \& Clarke, 2006) following the steps from Nowell et al., (2017). This study aims to explore the perceptions of elementary and junior high school teachers regarding the application of character education in schools, the relevance of character to meaning in life and well-being, and the role of parents, teachers, and the 
surrounding community in supporting students' character education, meaningfulness of life, and wellbeing.

\section{Method and Materials}

\subsection{Research Design}

The research data was then processed using a qualitative survey analysis approach. The research instrument used was an interview guide containing open questions relating to the application of character education at the elementary/junior high school level; the character, life purpose, and well-being of students; and the role of teachers and related parties in developing the character education, meaning and purpose in life, and well-being of students. The teachers were asked to complete their answers independently and send them via email to the researchers.

\subsection{Participants}

Participants were 10 elementary school teachers and 10 junior high school teachers from five schools. These teachers were all character subject teachers, vice-principals in student affairs, or homeroom teachers. Therefore, the researchers can cross-check the answers from participants since each school has at least two representatives. All participants gave written informed consent. The ethical process was performed for the study despite the absence of formal institutional procedure.

\subsection{Data Collection Tools}

The researchers developed interview guidelines based on the curriculum and implementation of character education as well as the theoretical concept of meaning in life and well-being. The researchers developed six questions about the teacher's biodata. For example, their teaching experience and their specific role in teaching and administrative position. Furthermore, there were five questions about how character education has been applied at the school, six questions about meaning in life among students, and three questions related to students' well-being.

\subsection{Data Collection Process}

All participants were sent several questions about character, meaning in life, well-being. They were required to provide written answers and to send their answer to the researchers. The researchers contacted teachers via telephone to clarify unclear answers.

\subsection{Data Collection Analysis}

All teams reviewed all teachers' interview data to familiarize with the data. Initial codes were generated as the framework, but research teams were allowed to add. Each participant's answer was coded by two members of the research team. If there were differences in the codes given, they were discussed by the team members to come to an agreement. Three members of the research team identified and discussed themes from the teachers' answers as a whole. The data can be provided upon request.

\section{Results}

As presented in Table 1, most teachers perceived that their school defined specific characters as the focus of their character education curriculum in which all teachers were involved. More than half of the participants acknowledged that the teacher wrote an evaluation for each student's character but less than half participants felt that their assessment in character education was conducted in a systematic way. The 
Livia Yuliawati, Stefani Virlia, Meilani Sandjaja, Tasia Puspa Sari, Mopheta Audiola Dorkas, \& Oktufiani Dwi Wulansari (2021). Character, meaning in life, and well-being of students from teachers' perspective. Cypriot Journal of Educational Science. 16(6), 3073-3090. https://doi.org/10.18844/cjes.v16i6.6497

progress of students in their character development was regarded as the positive impact of character education (60\%) and the role of teachers and parents as the aspect that should be improved $(70 \%)$.

Table 1 Application of character education at the elementary/junior high school level

\begin{tabular}{cc}
\hline $\begin{array}{cc}\text { Application of character education at the elementary/junior high } \\
\text { school level }\end{array}$ & $\begin{array}{c}\text { Respondents who } \\
\text { answered "Yes" (\%) }\end{array}$
\end{tabular}

1. Character education curriculum in schools and its application:

a. There is a set of specific characteristics as a reference $65 \%$

b. Character studies is a separate subject $35 \%$

2. Parties involved in the application of character education in schools:

a. Teachers or coordinators are involved in the application of $\quad 70 \%$ character education

b. The role of the teachers or coordinators involved is explained $20 \%$

3. Evaluation of character education in schools:

a. There is a written character evaluation for each student $65 \%$

b. There is a quantitative assessment of student character $40 \%$

c. There is a rubric, written worksheet for student evaluation $\quad 35 \%$

d. Character education evaluations conducted have been $\quad 40 \%$

meaningful/internalized/appreciated.

4. Positive aspects of the implementation of character education

in schools:

$\begin{array}{ll}\text { a. Student development } & 60 \%\end{array}$

b. Curriculum/methods/materials $15 \%$

c. Implementers (teachers/parents) $\quad 45 \%$

d. Meaning/internalization/appreciation $\quad 40 \%$

5. Aspects of the implementation of character education in schools that need to be improved:
a. Student development
$35 \%$
b. Curriculum/methods/materials
$30 \%$
c. Implementers (teachers/parents)
$70 \%$ 
Table 2 provides what teachers perceive about character, purpose in life, and wellbeing of their students. A majority of participants tended to associate purpose with contribution for beyond-the-self and with one's faith. Participants observed that during character development, students showed indications of discovering meaning and purpose in life. Participants inferred that having meaning and purpose was derived from one's assets than one's external supports. Nearly half of participants mentioned the contributing role of good habits from character education for purpose in life. All participants also agreed that character education played a key role in students' academic achievement. Regarding wellbeing, 30\% of participants evaluated their student's level of well-being was good but only $35 \%$ of participants mentioned the need to improve it.

Table 2 Character, purpose in life, and well-being of students

\begin{tabular}{cc}
\hline Character, purpose in life, and well-being of students & $\begin{array}{c}\text { Respondents who } \\
\text { answered "Yes" (\%) }\end{array}$ \\
\hline
\end{tabular}

1. There are specific characteristic that are important to foster in elementary/junior high school students

2. Understanding of meaning and purpose in life:

a. A main/long-term goal in life $55 \%$

b. Sense of meaning/life worth living $50 \%$

c. Ability to understand life experiences in the past, present, and $65 \%$ future

d. The role/contribution/goal of others/God/things matters $\quad 70 \%$ beyond-the-self

e. Elements related to religion/faith $\quad 60 \%$

3. Examples of students who show indications of having meaning and purpose in life, and the characteristics of those students:

a. There are examples of students who show indications of $\quad 85 \%$ having meaning and purpose in life b. Student character involves internal factors (knowledge, skills, $\quad 100 \%$ personality, etc.)

c. Student character involves external factors (family harmony, involvement in the spiritual community, neighborhood environment, etc.)

4. The role of character education in schools in contributing to students finding a purpose and meaning in life: 
Livia Yuliawati, Stefani Virlia, Meilani Sandjaja, Tasia Puspa Sari, Mopheta Audiola Dorkas, \& Oktufiani Dwi Wulansari (2021). Character, meaning in life, and well-being of students from teachers' perspective. Cypriot Journal of Educational Science. 16(6), 3073-3090. https://doi.org/10.18844/cjes.v16i6.6497

a. There are topics/discussions about meaning and purpose in life

$35 \%$

in character studies

b. There is a role of inspiration/role model/personal interaction

$20 \%$

with students

c. There are activities (e.g., extracurricular activities, projects,

$30 \%$

etc.) in school that contribute to meaning and purpose in life

d. There is the formation of good habits/self-regulation, etc.

$45 \%$

5. Character education and academic achievement of students:

a. Character education influences the academic achievement of

$100 \%$

students:

b. There are specific characteristics that influence the academic

$80 \%$

achievement of students

6. Student well-being

a. The well-being of students is considered to be good

$30 \%$

b. The well-being of students needs to be improved

$35 \%$

Table 3 presented how many teachers perceived the importance of external supports on students' character, purpose, and wellbeing. Interaction between parents, teachers, and communities was frequently mentioned by participants to facilitate character and purpose development as well as wellbeing among students but less than half of the participants could specify how the role of each party in fostering students' purpose and wellbeing.

Table 3 Role of teachers and related parties

\begin{tabular}{cc}
\hline Role of teachers and related parties & $\begin{array}{c}\text { Respondents who } \\
\text { answered "Yes" (\%) }\end{array}$ \\
\hline
\end{tabular}

1. The role and involvement of teachers, parents, and the

community in developing the character of elementary/junior high

school students:

a. The role of each party is specified

$45 \%$

b. Inspiration/role models

$50 \%$

c. Cooperation/communication/interaction

$70 \%$

d. Ideas for activities/ongoing activities

$30 \%$

2. The role and involvement of teachers, parents, and the community in developing meaning and purpose in the lives of 

in life, and well-being of students from teachers' perspective. Cypriot Journal of Educational Science. 16(6), 3073-3090. https://doi.org/10.18844/cjes.v16i6.6497

elementary/junior high school students:

a. The role of each party is specified $30 \%$

b. Inspiration/role models $35 \%$

c. Cooperation/communication/interaction $80 \%$

d. Ideas for activities/ongoing activities $45 \%$

3. The role and involvement of teachers, parents, and the community in improving the well-being of elementary/junior high school students:

a. The role of each party is specified

b. Inspiration/role models

c. Cooperation/communication/interaction

\subsection{Character Education from a Teacher's Perspective}

There are several important themes raised by teachers regarding their thoughts on character education. Firstly, the application of character education. According to the teachers, there are different methods in applying character education: intracurricular, co-curricular, and integration into subjects. In the intracurricular method, character education is a separate subject that has set weekly teaching and learning times. Character education is also applied through the cocurricular method, through designing activities/projects to help students to strengthen the characteristics taught. Parents are also made aware of these activities/projects and progress made by students recorded in the form of journals and various other means. In addition, the application of character education is also integrated into school subjects, like what have been shared by an elementary school teacher:

"The character education curriculum in our school is a school character education that is integrated holistically with the fields of study in schools ... In its application, character education is also equipped with measures for the achievement of student targets according to school standards."

Secondly, evaluation of character education. The teachers stated that character education applied using the intracurricular method is evaluated using various instruments, such as assessment sheets according to school indicators (assessment rubric), projects, and qualitative records made by teachers. In addition, the teachers stated that character education can also be evaluated by observing students' application of character in their daily activities. For example:

"There are no grades in this lesson that are included in the report card. The evaluation is based on the teacher's observations of student character and communicated with the homeroom teacher or other subject teachers. The homeroom teacher can also confirm to the parents whether students also experience problems outside of school as well."

Thirdly, parties involved in the implementation of character education. The teachers stated that in addition to the school, parents and the environment should also be involved in implementing character education. Therefore, it is important for schools, parents, and the community to be able to cooperate in implementing character education. However, the teachers also realized that the level of parental 
Livia Yuliawati, Stefani Virlia, Meilani Sandjaja, Tasia Puspa Sari, Mopheta Audiola Dorkas, \& Oktufiani Dwi Wulansari (2021). Character, meaning in life, and well-being of students from teachers' perspective. Cypriot Journal of Educational Science. 16(6), 3073-3090. https://doi.org/10.18844/cjes.v16i6.6497

involvement and the environment of students can differ from one another. For example, one teacher noticed that "what needs to be improved, especially is the support of parents so that character education is consistent at school and at home. Perhaps because of parent's monitoring system or socialization to their parents is lacking."

\subsection{Meaning and Purpose in Life from a Teacher's Perspective}

There are several important themes raised by teachers regarding their thoughts on meaning and purpose in life. Firstly, the existence of self-interest and matters that exist beyond-the-self in the meaning and purpose of an individual's life. The teachers stated that meaning and purpose in life are related to "awareness of one's potential and its actualization", as well as "how individuals obtain happiness in life", and also as "a form of servitude to God and being of value to others."

Secondly, the contribution of character to meaning and purpose in students' lives. The teachers mentioned several important characteristics developed by students that are also evident in students who are goal oriented. These characteristics include caring for others (empathy, tolerance), resilience and selfcontrol (determination, discipline, responsibility), belief in oneself (confidence, curiosity), and religiosity (fear of God). According to the teachers, these characteristics not only contribute to meaning and purpose in students' lives but also to their academic achievement. One teacher perceived that "...because of the character education, students are more motivated and have more direction in the learning process."

Thirdly, the teachers emphasized the role of character education in schools in helping students find meaning and purpose in life. For example, "when students can recognize themselves, develop positive characters that are owned or that still need to be grown. This will directly impact their ability to interpret life and determine priorities for achieving strategies for fulfilling their life goals." Another teacher also asserts the role of character education in having meaning in life to "encourage a person when climbing steep paths, to strengthen when the way of life is turbulent and to hold back when the path of life is decreasing." Other participants added that inculcation of religious values, practices, and community in character education as a basis where students process and learn, and where there is consistency and habituation of student behavior, and a relationship between teachers and parents as role models for students.

\subsection{Student's Well-being from a Teacher's Perspective}

There are several important themes raised by teachers regarding their thoughts on student well-being. Firstly, teachers believed that well-being can be achieved if an individual can get positive things out of their life experiences, such as "feeling safe", "happy", and "satisfied with what they have achieved in their life." In addition, student well-being in the academic context cannot be separated from feelings of happiness and satisfaction when they achieve their expected academic outcomes. Since the main task of students is achieving optimal academic outcomes, they will experience pride and satisfaction when their learning process was deemed successful.

Secondly, teachers also believed that there are several factors that influence the level of students' wellbeing. These factors include family background, such as the socio-economic status, parent's educational background, and parenting style also affect students' well-being. Students from an upper middle class socio-economic background have adequate facilities to access better quality education. In addition, the values and character education applied through upbringing and parenting also affect students' well-being. This was asserted in this teacher's statements, "teachers, parents, and community consistently supervise 
Livia Yuliawati, Stefani Virlia, Meilani Sandjaja, Tasia Puspa Sari, Mopheta Audiola Dorkas, \& Oktufiani Dwi Wulansari (2021). Character, meaning in life, and well-being of students from teachers' perspective. Cypriot Journal of Educational Science. 16(6), 3073-3090. https://doi.org/10.18844/cjes.v16i6.6497

students' activity and provide support with the right response if students face difficulties. These supportive parties can work in synergy to make positive characters in everyday life to improve the well-being."

In addition to family background, peer environment also affects student well-being since they might imitate their peer behavior to gain acceptance. The next factor is that academic demands that are too great and become burdensome for children can reduce their well-being because they become overloaded and unhappy about their lives. In addition, children's motivation to participate in the learning process in school can also influence student well-being. The last factor is whether the facilities provided by the school include classrooms that are comfortable and appropriate for the learning process, adequate services for students who require assistance or counselling, and so forth.

Thirdly, teachers believed that not only teachers but the entire school community and parents need to be involved in efforts to improve student well-being. For example, "in the case of students cutting the queue when buying food from the canteen, canteen workers can remind students that learning to be tolerant of others starts from simple things like waiting in line." The involvement of parents and consistency of perceptions between schools and parents also need to be developed. An important point in developing character education is to focus not only on academic performance, but also on selfawareness and developing positive characteristics that will increase the life satisfaction of students in the future.

Fourthly, teachers believed that the roles of students' parents, teachers, and community can increase student well-being by becoming positive role models for students. One participant said that "lack of support from significant others has an impact on the behavior of children who tend not to know what they want to be, indicating problems at home and at school." It cannot be denied that students require assistance and direction from the adults around them, including teachers and parents, meaning they need to display characters and behaviors that provide positive examples for students. Furthermore, teachers and parents also need to accustom children to applying positive characteristics and act as mentors when they need constructive advice and feedback. Teachers and parents must also provide support and motivation for students so that they can build a positive community among their friends. Finally, students should also participate in social service activities to increase their empathy and tolerance for others and undergo routine health check-ups to ensure that they remain physically healthy.

\section{Discussion}

The term character education is commonly implemented in school's context. In Indonesia, character education is stringently carried out in schools at all educational levels, from kindergartens to senior high schools (Maunah, 2015; Sultoni, 2016). This is because character education is necessary to improve and advance Indonesia as a nation, especially among the younger generation, including students (Purnomo, 2014). In the responses provided by the teachers, many stated that it is important to implement character education in an educational setting in order to change student behavior and not only focus on improving academic grades. There are different characteristics that are considered important and developed in each school, such as kindness, tolerance, empathy, creativity, perseverance, determination, self-control, responsibility, independence, respect for others, and fear of God. The number of characteristics instilled in students gave rise to different viewpoints among the researchers. There are many different types of characteristics instilled in students with some overlapping. This large number of characteristics gives rise to the assumption that there are a lot of character problems among students as well (Sultoni, 2016). In contrast, Purnomo (2014) argues that the problem of character education does not lie in which characteristics are considered important and instilled, but in the delivery and in transferring the most 
Livia Yuliawati, Stefani Virlia, Meilani Sandjaja, Tasia Puspa Sari, Mopheta Audiola Dorkas, \& Oktufiani Dwi Wulansari (2021). Character, meaning in life, and well-being of students from teachers' perspective. Cypriot Journal of Educational Science. 16(6), 3073-3090. https://doi.org/10.18844/cjes.v16i6.6497

important characteristics to students and that these processes need to be further considered and improved in order to be more effective.

Character education is implemented using several methods: intracurricular, co-curricular, and integration into subjects. Based on the responses provided by the teachers, it is evident that character education has not been integrated into extracurricular activities, and in several cases has not been integrated into the school culture, even though it is best to conduct character education holistically and comprehensively (Astuti, 2010; Sudrajat, 2011). This method emphasizes and promotes collaboration and cooperation, as opposed to competition between students, and is open to giving students the opportunity to demonstrate and practice character-based values through activities inside and outside the classroom, where these values are embodied in extracurricular activities. In addition, all aspects of the school environment need to be managed to involve leaders, teachers, employees, the surrounding community, and students themselves, so that all members of the school community can develop and work together in order to create a school environment that is integrated with the characteristics instilled in students (Sudrajat, 2011).

The teachers mentioned that their role in character education is to act as a role model, provide information/knowledge, direct and assist students who are experiencing problems, and inform parents of the progress/constraints faced by students. Teachers play an important role in achieving the goals of character education. Teachers are figures who are emulated by students (Adawiah, 2016). In addition, teachers are also considered to have the large responsibility of creating a young generation with character and morals (Dalyono \& Lestariningsih, 2017). However, the development of student characteristics formed in schools needs to be monitored because students can still be influenced by their social environment (Arifudin, 2015). It can be concluded that character education can be implemented effectively if learning, role-modeling, reinforcement, and habituation are carried out simultaneously and consistently (Sudrajat, 2011). Meanwhile, according to the responses provided by teachers, some parents still do not fully support the implementation of character education in schools in that they are still not used to modeling positive values at home and leave the development and education of their children to the school. Therefore, it is important to realize that the implementation of character education requires the active involvement and cooperation of schools, parents, communities, and also the government (Purnomo, 2014; Ajmain \& Marzuki, 2019). The teachers did not mention the role of leaders or supervisors in implementing character education, meaning some teachers appeared to be less consistent in conducting character education, to have different viewpoints on certain characteristics, and to be passive in exploring materials and strategies to deliver character education. Therefore, after formulating and determining the methods of implementing character education, supervision is required (Sutjipto, 2011).

The teachers' understandings of meaning and purpose in life are consistent with the definitions presented in previous studies. For example, the existence of a long-term goal, a sense of meaning, and an understanding of past, present and future life experiences (George \& Park, 2017; Martela \& Steger, 2016). It is interesting that meaning in life plays a key role in teachers' well-being (Damasio et al., 2013). It is interesting to note that although not all researchers agree on the aspect of beyond-the-self being part of the definition of purpose in life (Damon et al., 2003; McKnight \& Kashdan, 2009; Steger et al., 2009), the majority of teachers mentioned a life that has positive benefits for others and living for God in their understanding about purpose in life.

In their responses to what they understand about meaning and purpose in life, many teachers mentioned elements of faith and religion. This is most likely related to the fact that most of the Indonesian population considers religion to be important (Poushter \& Fetterolf, 2019, April 22) and the application of religious-based values in private schools. Furthermore, this emphasizes the role of a person's religious 
Livia Yuliawati, Stefani Virlia, Meilani Sandjaja, Tasia Puspa Sari, Mopheta Audiola Dorkas, \& Oktufiani Dwi Wulansari (2021). Character, meaning in life, and well-being of students from teachers' perspective. Cypriot Journal of Educational Science. 16(6), 3073-3090. https://doi.org/10.18844/cjes.v16i6.6497

values in meaning and purpose in life (Abeyta \& Routledge, 2018; Aghababaei \& Błachnio, 2014; Mariano \& Damon, 2008).

Previous research has found that gratitude and compassion have a relationship with purpose in life (Malin et al., 2017). Gratitude was not specifically mentioned in the teachers' answers. They referred to characteristics related to religiosity in general, such as fear of God. Other studies have found that people who practice religious teachings tend to show higher scores in the characteristics of kindness, love, and gratitude, and in meaning in their lives (Berthold \& Ruch, 2014). It seems that the religious-based values that have been studied need to be introduced to educators to enhance their understanding and help them to put these characteristics in concrete implementation.

Teachers also considered the characteristic of caring for others to be important for meaning and purpose in life. As part of beyond-the-self orientation of purpose, caring for others helps individuals to recognize the needs of others and contribute positively to those needs. Aligned with that finding, another study found that being empathetic towards the needs of others, leading people to be involved in prosocial behavior (Malin et al., 2014) contributes to meaning and purpose in life (Van Tongeren et al., 2016). It is possible that caring for others fulfils one's basic psychological needs, especially relatedness, which in turn predicts the sense of meaning in life (Demirbas-Celik, 2018; Demirbas-Celik \& Keklik, 2019).

Consistent with the teachers' answers that resilience and self-confidence are important characteristics in the development of meaning and purpose in students' life, self-efficacy (DeWitz et al., 2009; Lane \& Schutts, 2014), curiosity and perseverance (Kashdan \& Steger, 2007; Lee et al., 2015) are predictors of purpose in life. However, in contrast to the Malin et al., (2017) study, where grit was not mentioned in the interviews, the teachers in this study mentioned resilience and self-confidence - which are related to grit - as important characteristics for students to have in finding meaning and purpose in their lives. Considering that in previous studies purpose was a predictor of grit (Hill et al., 2016), it is recommended that the development of meaning and purpose in students' lives be conducted simultaneously with character education.

To what extent are teachers aware of their role in developing meaning and purpose in students' lives? The majority of teachers emphasized communication with students and collaboration with parents as being important. Furthermore, collaboration with parents was also considered to be important in the development of students' character and well-being. Unfortunately, not many of the teachers' responses identified the specific roles of the teacher and the parents. Even fewer mentioned specific role models or activities that consistently contribute to the development of meaning in students' lives. However, parents and teachers are external sources of support that are assets to students. The role of parents in sharing life values, creating dialogue so that their children can reflect on life experiences, and acting as role models, is the basis for the development of meaning and purpose in life (Bronk, 2013; Malin et al., 2014). Meanwhile, the role of the school is to provide meaningful lessons, mentors and role models for students, and career counselling programs (Bronk, 2013).

Collaboration between academic, social, and emotional learning has five core social and emotional competencies which form an important foundation for adolescent well-being, including self-awareness, social awareness, self-management, relationship skills, and responsible decision-making (Ashdown \& Bernard, 2012). According to Shonkoff \& Philips (2000), children need these social-emotional skills when they start school, such as self-confidence, the capacity to build positive relationships with friends and teachers, endurance to complete difficult tasks, the ability to communicate, the ability to pay attention and listen to instructions, and problem-solving skills (Ashdown \& Bernard, 2012). Consistent with the teachers, student well-being is also affected by the aspect of popularity among peers, where positive relationships can influence children to be more positive because friends can also provide examples or act 
Livia Yuliawati, Stefani Virlia, Meilani Sandjaja, Tasia Puspa Sari, Mopheta Audiola Dorkas, \& Oktufiani Dwi Wulansari (2021). Character, meaning in life, and well-being of students from teachers' perspective. Cypriot Journal of Educational Science. 16(6), 3073-3090. https://doi.org/10.18844/cjes.v16i6.6497

as role models for children. In addition, the teachers also emphasized children's determination and perseverance when faced with difficult problems. When children are successful in overcoming difficult challenges, they feel satisfied and happy. Supporting these findings, it seems that there were potentially a bidirectional relationship between meaning in life and well-being (Howell et al., 2013; Rathi \& Rastogi, 2007).

Students' experiences in school are also an important indicator that can hinder or facilitate the success of student development over the course of their life (Bucker et al., 2018). Studies on school effectiveness predominantly focus on cognitive outcomes, especially in the fields of mathematics, language, and science. However, Noddings (2003; as cited in Bucker et al., 2018) states that happiness and education are closely related. Happiness must be an educational goal, and good education should significantly contribute to personal and collective happiness. This is consistent with the teachers statements that student well-being is not only contingent on academic achievements, but also on relationships with others. Therefore, the teachers also may emphasize the importance of being empathetic and helping one another, which gives students who are successful in being beneficial to or impacting others a sense of satisfaction and happiness.

Research shows that students with high levels of well-being see themselves developing in their personal life and achieving their life goals, which in turn contributes to their self-acceptance and interpersonal relationships. In addition, students with high levels of well-being can sense positive developments in their school or community, which ultimately also has an impact on their relationship with the wider community and generally they experience more positive feelings and life satisfaction (Cadime et al., 2016). This concern was also expressed by the teachers; that the schools, parents and communities around children can work together to help improve their well-being, through which children will feel a sense of acceptance and support from their environment to be able to achieve their life goals.

\section{Conclusion}

This study aims to explore teachers' perceptions about character, meaning in life, and well-being. In teachers' perception, it is important to implement character education in an educational setting to change student behavior and not only focus on improving academic grades. However, it turns out that character education has not been integrated into extracurricular activities, and in several cases has not been integrated into the school culture, even though it is best to conduct character education holistically and comprehensively. Cooperation is needed that involves all aspects of the school such as leaders, teachers, employees, the surrounding community, and the students them-selves, so that all school members can develop and work together to create an integrated school environment with the characteristics instilled in students.

Teachers understand the meaning and purpose of life as long-term goals, a sense of meaning, and an understanding of past, present and future life experiences. The majority of teachers mentioned a life of having positive benefits for others and living for God in their understanding of the purpose of life. Faith and religion are important in understanding the purpose of life. Teachers also consider the characteristic of caring for others important for the meaning and purpose of life. Concern for others helps individuals to recognize the needs of others and contribute positively to those needs. The teacher also views that resilience and self-confidence are important characteristics in the development of students' meaning and purpose in life, self-efficacy, curiosity, and perseverance are predictors of life goals. Many teachers emphasize communication with students and collaboration with parents as important for the development of meaning and purpose in life. In addition, cooperation with parents is also considered important in character development and student welfare. The role of parents is manifested in the form of sharing life values, creating dialogue so that their children can re-flex on life experiences, and being role 
models. Meanwhile, the school's role is to provide meaningful lessons, mentors and role models for students, and career counselling programs.

\section{Recommendations}

Collaboration between academic, social, and emotional learning has five core social and emotional competencies that form an important foundation for adolescent well-being. The teacher views that students' well-being is also influenced by aspects of popularity among peers, as well as children's determination and perception when facing difficult problems. The teacher also stated that students' wellbeing does not only depend on academic achievement, but also on relationships with other people. Therefore, teachers can also emphasize the importance of empathizing and helping one another, which gives students a sense of satisfaction and happiness for those who succeed in benefiting or having an impact on others. Students with high levels of well-being can experience positive developments in their school or community, which in turn also affects their relationship with the wider community and generally they experience more positive feelings and life satisfaction. The teachers also hope that the school, parents, and the community around the child can work together by providing acceptance and support to help improve their well-being so that they can achieve their life goals.

\section{Acknowledgment}

The authors would like to express our deepest gratitude to the school principals who helped and especially to the teachers who participated in this research. The authors acknowledge the funding support from Indonesia Higher Education Research Grants (Hibah Penelitian - DIKTI).

\section{References}

Abdia \& Sailan, M. (2017). Perspektif guru tentang pendidikan karakter (Studi di MAN 1 Buton Tengah). Jurnal Pemikiran, Penelitian Hukum, Pendidikan Pancasila dan Kewarganegaraan, 4(2), 230-241. https://ojs.unm.ac.id/tomalebbi/article/view/3734

Abdullah, I., Hudayana, B., Kutanegara, P. M., \& Indiyanto, A. (2019). Beyond school reach: Character education in three schools in Yogyakarta, Indonesia. Journal of Educational and Social Research, 9(3), 145-159. https://doi.org/10.2478/jesr-2019-0032

Abeyta, A. A., \& Routledge, C. (2018). The need for meaning and religiosity: An individual differences approach to assessing existential needs and the relation with religious commitment, beliefs, and experiences. Personality and Individual Differences, 123, 6-13. https://doi.org/10.1016/j.paid.2017.10.038

Adawiah, R. (2016). Profesionalitas guru dan pendidikan karakter (Kajian empiris di SDN Kabupaten Balangan). Jurnal $\begin{array}{lll}\text { Pendidikan Kewarganegaraan, 6(11), 940-946. } & \end{array}$ https://ppjp.ulm.ac.id/journal/index.php/pkn/article/view/731

Aghababaei, N., \& Błachnio, A. (2014). Purpose in life mediates the relationship between religiosity and happiness: Evidence from Poland. Mental Health, Religion \& Culture, 17(8), 827-831. https://doi.org/10.1080/13674676.2014.928850

Ajmain, A., \& Marzuki, M. (2019). Peran guru dan kepala sekolah dalam pendidikan karakter siswa di SMA Negeri 3 Yogyakarta. SOCIA: Jurnal Ilmu-Ilmu Sosial, 16(1), 109-123. https://doi.org/10.21831/socia.v16i1.27655 
Livia Yuliawati, Stefani Virlia, Meilani Sandjaja, Tasia Puspa Sari, Mopheta Audiola Dorkas, \& Oktufiani Dwi Wulansari (2021). Character, meaning in life, and well-being of students from teachers' perspective. Cypriot Journal of Educational Science. 16(6), 3073-3090. https://doi.org/10.18844/cjes.v16i6.6497

Arifudin, I. S. (2015). Peranan guru terhadap pendidikan karakter siswa di Kelas V SDN 1 Siluman. PEDADIDAKTIKA: Jurnal IImiah Pendidikan Guru Sekolah Dasar, 2(2), 175-186. https://ejournal.upi.edu/index.php/pedadidaktika/article/view/5844

Ashdown, D. M., \& Bernard, M. E. (2011). Can explicit instruction in social and emotional learning skills benefit the social-emotional development, well-being, and academic achievement of young children? Early Childhood Education Journal, 39(6), 397-405. https://doi.org/10.1007/s10643-011-0481-x

Astuti, S. I. (2010). Pendekatan holistik dan kontekstual dalam mengatasi krisis karakter di Indonesia. Jurnal Cakrawala Pendidikan, 1(3), 41-58. https://journal.uny.ac.id/index.php/cp/article/view/234

Author, \& Co-Author (2014)

Berthold, A., \& Ruch, W. (2014). Satisfaction with life and character strengths of non-religious and religious people: It's practicing one's religion that makes the difference. Frontiers in Psychology, 5(876). https://doi.org/10.3389/fpsyg.2014.00876

Braun, V., \& Clarke, V. (2006). Using thematic analysis in psychology. Qualitative Research in Psychology, 3(2), 77101. https://doi.org/10.1191/1478088706qp063oa

Bronk, K. C. (2011). A grounded theory of the development of noble youth purpose. Journal of Adolescent Research, 27(1), 78-109. https://doi.org/10.1177/0743558411412958

Bronk, K. C. (2012). The exemplar methodology: An approach to studying the leading edge of development. Psychology of Well-Being: Theory, Research and Practice, 2(1), 5. https://doi.org/10.1186/2211-1522-2-5

Bronk, K. C. (2013). Purpose in life: A critical component of optimal youth development. Springer.

Bücker, S., Nuraydin, S., Simonsmeier, B. A., Schneider, M., \& Luhmann, M. (2018). Subjective well-being and academic achievement: A meta-analysis. Journal of Research in Personality, 74, 83-94. https://doi.org/10.1016/j.jrp.2018.02.007

Cadime, I., Pinto, A. M., Lima, S., Rego, S., Pereira, J., \& Ribeiro, I. (2016). Well-being and academic achievement in secondary school pupils: The unique effects of burnout and engagement. Journal of Adolescence, 53, 169179. https://doi.org/10.1016/j.adolescence.2016.10.003

Cohen, R., Bavishi, C., \& Rozanski, A. (2016). Purpose in life and its relationship to all-cause mortality and cardiovascular events. Psychosomatic Medicine, 78(2), 122-133. https://doi.org/10.1097/psy.0000000000000274

Dalyono, B., \& Lestariningsih, E. D. (2016). Implementasi penguatan pendidikan karakter di sekolah. Bangun Rekaprima: Majalah Ilmiah Pengembangan Rekayasa, Sosial dan Humaniora, 3(2), 33-42. https://jurnal.polines.ac.id/index.php/bangun_rekaprima/article/view/865

Damon, W., Menon, J., \& Bronk, K. C. (2003). The development of purpose during adolescence. Applied Developmental Science, 7(3), 119-128. https://doi.org/10.1207/S1532480XADS0703_2

Damásio, B. F., Melo, R. L. P. D., \& Silva, J. P. D. (2013). Meaning in life, psychological well-being and quality of life in $\begin{array}{lllll}\text { teachers. } & \text { Paidéia } & \text { 73-82. }\end{array}$ https://www.researchgate.net/publication/258883590_Meaning_in_Life_Psychological_WellBeing_and_Quality_of_Life_in_Teachers

Demirbaş-Çelik, N. (2018a). Mental well-being predictivity of personal meaning profile in various age groups. Journal of Education and Training Studies, 6(10), 198. https://doi.org/10.11114/jets.v6i10.3490

Demirbaş-Çelik, N. (2018b). Happiness in high school students: Autonomy, relatedness, competence and meaning in life. Cypriot Journal of Educational Sciences, 13(3), 422-430. https://doi.org/10.18844/cjes.v13i3.3561

Demirbaş-Çelik, N., \& Keklik, i. (2018). Personality factors and meaning in life: The mediating role of competence, relatedness and autonomy. Journal of Happiness Studies, 20(4), 995-1013. https://doi.org/10.1007/s10902-018-9984-0 
Livia Yuliawati, Stefani Virlia, Meilani Sandjaja, Tasia Puspa Sari, Mopheta Audiola Dorkas, \& Oktufiani Dwi Wulansari (2021). Character, meaning in life, and well-being of students from teachers' perspective. Cypriot Journal of Educational Science. 16(6), 3073-3090. https://doi.org/10.18844/cjes.v16i6.6497

DeWitz, S. J., Woolsey, M. L., \& Walsh, W. B. (2009). College student retention: An exploration of the relationship between self-efficacy beliefs and purpose in life among college students. Journal of College Student Development, 50(1), 19-34. https://doi.org/10.1353/csd.0.0049

Dwiningrum, S.I.A., \& Purbani, W. (2012). Manusia berkarakter dalam perspektif guru dan siswa. Jurnal Kependidikan: Penelitian Inovasi Pembelajaran, 42(1), 76-88. https://doi.org/10.21831/jk.v42i1.2234

Faridi, A. (2014). The difficulties of English teachers in instilling character building through narrative stories at elementary schools in Central Java, Indonesia. International Journal of Contemporary Applied Sciences, 1(2), 68-82. http://ijcar.net/assets/pdf/Vol1-No2-October2014/05.pdf

Frankl, V. E., Lasch, I., \& Frankl, V. E. (1963). Man's search for meaning an introd. to logotherapy. Beacon Press.

George, L. S., \& Park, C. L. (2017). The multidimensional existential meaning scale: A tripartite approach to measuring meaning in life. The Journal of Positive Psychology, 12(6), 613-627. https://doi.org/10.1080/17439760.2016.1209546

Harzer, C. (2016). The eudaimonics of human strengths: The relations between character strengths and well-being. Handbook of Eudaimonic Well-Being, 307-322. https://doi.org/10.1007/978-3-319-42445-3_20

Hill, P. L., Burrow, A. L., \& Bronk, K. C. (2016). Persevering with positivity and purpose: An examination of purpose commitment and positive affect as predictors of grit. Journal of Happiness Studies, 17(1), 257-269. https://doi.org/10.1007/s10902-014-9593-5

Hill, P. L., Turiano, N. A., Mroczek, D. K., \& Burrow, A. L. (2016). The value of a purposeful life: Sense of purpose predicts greater income and net worth. Journal of Research in Personality, 65, 38-42. https://doi.org/10.1016/j.jrp.2016.07.003

Howell, A. J., Passmore, H.-A., \& Buro, K. (2013). Meaning in nature: Meaning in life as a mediator of the relationship between nature connectedness and well-being. Journal of Happiness Studies, 14(6), 1681-1696. https://doi.org/10.1007/s10902-012-9403-x

Isdaryanti, B., Rahman, M., Sukestiyarno, Y. L., Florentinus, T. S., \& Widodo, W. (2018). Teachers' performance in science learning management integrated with character education. Jurnal Pendidikan IPA Indonesia, 7(1), 9-15. https://doi.org/10.15294/jpii.v7i1.12887

Kashdan, T. B., \& Steger, M. F. (2007). Curiosity and pathways to well-being and meaning in life: Traits, states, and everyday behaviors. Motivation and Emotion, 31(3), 159-173. https://doi.org/10.1007/s11031-007-90687

Kim, E. S., Sun, J. K., Park, N., \& Peterson, C. (2013). Purpose in life and reduced incidence of stroke in older adults: 'The Health and Retirement Study'. Journal of Psychosomatic Research, 74(5), 427-432. https://doi.org/10.1016/j.jpsychores.2013.01.013

Komalasari, K., \& Saripudin, D. (2018). The influence of living values education-based civic education textbook on student's character formation. International Journal of Instruction, 11(1), 395-410. https://doi.org/10.12973/iji.2018.11127a

Lane, F. C., \& Schutts, J. W. (2014). Predicting the presence of purpose through the self-efficacy beliefs of one's talents. Journal of College and Character, 15(1). https://doi.org/10.1515/jcc-2014-0003

Lee, J. N., Foo, K. H., Adams, A., Morgan, R., \& Frewen, A. (2015). Strengths of character, orientations to Happiness, Life Satisfaction and purpose in Singapore. Journal of Tropical Psychology, 5. https://doi.org/10.1017/jtp.2015.2

Lerner, R. M. (2018). Character development: Four facets of virtues. Child Development Perspectives, 13(2), 79-84. https://doi.org/10.1111/cdep.12315 
Livia Yuliawati, Stefani Virlia, Meilani Sandjaja, Tasia Puspa Sari, Mopheta Audiola Dorkas, \& Oktufiani Dwi Wulansari (2021). Character, meaning in life, and well-being of students from teachers' perspective. Cypriot Journal of Educational Science. 16(6), 3073-3090. https://doi.org/10.18844/cjes.v16i6.6497

Lestari, T. F. (2012). Persepsi guru matematika SMA Se-Kecamatan Kota Kabupaten Kudus mengenai pengintegrasian pendidikan karakter dalam pembelajaran (Doctoral dissertation, Universitas Muhammadiyah Surakarta). http://eprints.ums.ac.id/17736/1/02._halaman_depan.pdf

Malin, H., Liauw, I., \& Damon, W. (2017). Purpose and character development in early adolescence. Journal of Youth and Adolescence, 46(6), 1200-1215. https://doi.org/10.1007/s10964-017-0642-3

Malin, H., Reilly, T. S., Quinn, B., \& Moran, S. (2014). Adolescent purpose development: Exploring empathy, discovering roles, shifting priorities, and creating pathways. Journal of Research on Adolescence, 24(1), 186-199. https://doi.org/10.1111/jora.12051

Mariano, J. M., \& Damon, W. (2008). The role of spirituality and religious faith play in supporting purpose in adolescence. In R. M. Benson, R. W. Roeser, \& E. Phelps (Eds.), Positive youth development and spirituality: From theory to research (pp. 210-230). Templeton.

Martela, F., \& Steger, M. F. (2016). The three meanings of meaning in life: Distinguishing coherence, purpose, and significance. The Journal of Positive Psychology, 11(5), 531-545. https://doi.org/10.1080/17439760.2015.1137623

Masten, A. S., \& Reed, M.-G. J. (2002). Resilience in development. In C. R. Snyder \& S. J. Lopez (Eds.), Handbook of positive psychology (pp. 74-88). Oxford University Press.

Maulana, H., Obst, T., \& Khawaja, N. (2018). Indonesian perspective of wellbeing: A qualitative study. Qualitative Report, 23(12), 3136-3152. https://doi.org/10.46743/2160-3715/2018.3508

Maunah, B. (2015). Implementasi pendidikan karakter dalam pembentukan kepribadian holistik siswa. Jurnal Pendidikan Karakter, 6(1), 90-101. https://doi.org/10.21831/jpk.v0i1.8615

McKnight, P. E., \& Kashdan, T. B. (2009). Purpose in life as a system that creates and sustains health and well-being: An integrative, testable theory. Review of General Psychology, 13(3), 242-251. https://doi.org/10.1037/a0017152

Nowell, L. S., Norris, J. M., White, D. E., \& Moules, N. J. (2017). Thematic analysis: Striving to meet the trustworthiness criteria. International Journal of Qualitative Methods, 16(1), 1-13. https://doi.org/10.1177/1609406917733847

Park, N. (2004). Character strengths and positive youth development. The ANNALS of the American Academy of Political and Social Science, 591(1), 40-54. https://doi.org/10.1177/0002716203260079

Peterson, C., \& Seligman, M. E. P. (2004). Character strengths and virtues: A handbook and classification. Oxford University Press.

Poushter, J., \& Fetterolf, J. (2019, April 22). How people around the world view religion's role in their countries. Retrieved May 27, 2021, from https://www.pewresearch.org/global/2019/04/22/how-people-aroundthe-world-view-religions-role-in-their-countries/.

Purnomo, S. (2014). Pendidikan karakter di Indonesia antara asa dan realita. Jurnal Kependidikan, 2(2), 67-68. https://doi.org/https://doi.org/10.24090/jk.v2i2.553

Rathi, N., \& Rastogi, R. (2007). Meaning in life and psychological well-being in pre-adolescents and adolescents. Journal of the Indian Academy of Applied Psychology, 33(1), 31-38. https://www.researchgate.net/publication/268299281_Meaning_in_Life_and_Psychological_WellBeing_in_Pre-Adolescents_and_Adolescents

Rokhman, F., Hum, M., Syaifudin, A., \& Yuliati. (2014). Character education for golden generation 2045 (national character building for Indonesian golden years). Procedia - Social and Behavioral Sciences, 141, 1161-1165. https://doi.org/10.1016/j.sbspro.2014.05.197

Sadia, W. (2013). Model pendidikan Karakter Terintegrasi Pembelajaran Sains. JPI (Jurnal Pendidikan Indonesia), 2(2). https://doi.org/10.23887/jpi-undiksha.v2i2.2165 

in life, and well-being of students from teachers' perspective. Cypriot Journal of Educational Science. 16(6), 3073-3090. https://doi.org/10.18844/cjes.v16i6.6497

Saputro, J. D., \& Murdiono, M. (2020). International Journal of Multicultural and Multireligious understanding implementation of character education through a holistic approach to senior high school students. International Journal of Multicultural and Multireligious Understanding, 7(11), 460-470. https://webcache.googleusercontent.com/search?q=cache:hkvFXHOrxbUJ:https://ijmmu.com/index.php/ ijmmu/article/download/2146/1916+\&cd=1\&hl=en\&ct=clnk\&gl=id

Schnitker, S. A. (2012). An examination of patience and well-being. The Journal of Positive Psychology, 7(4), 263-280. https://doi.org/10.1080/17439760.2012.697185

Shoshani, A., \& Shwartz, L. (2018). From character strengths to children's well-being: Development and validation of the Character Strengths Inventory for Elementary School Children. Frontiers in Psychology, 9. https://doi.org/10.3389/fpsyg.2018.02123

Shonkoff, J. P., \& Phillips, D. A. (Eds.). (2000). From neurons to neighborhoods: The science of early childhood development. National Academy Press.

Steger, M. F., Frazier, P., Oishi, S., \& Kaler, M. (2006). The meaning in life questionnaire: Assessing the presence of and search for meaning in life. Journal of Counseling Psychology, 53(1), 80-93. https://doi.org/10.1037/0022-0167.53.1.80

Steger, M. F., Oishi, S., \& Kashdan, T. B. (2009). Meaning in life across the life span: Levels and correlates of meaning in life from emerging adulthood to older adulthood. Journal of Positive Psychology, 4(1), 43-52. https://doi.org/10.1080/17439760802303127

Sudrajat, A. (2011). Mengapa pendidikan karakter? Jurnal Pendidikan Karakter, 1(1), 47-58. https://journal.uny.ac.id/index.php/jpka/article/view/1316

Sultoni, A. (2016). Pendidikan Karakter dan Kemajuan Negara: Studi Perbandingan Lintas Negara. JOIES: Journal of Islamic Education Studies Universitas Negeri Malang, 1(1), 167-188. http://jurnalpps.uinsby.ac.id/index.php/joies/article/view/9

Sutjipto, S. (2011). Rintisan pengembangan pendidikan karakter di satuan pendidikan. Jurnal Pendidikan dan Kebudayaan, 17(5), 501-524. https://jurnaldikbud.kemdikbud.go.id/index.php/jpnk/article/view/45

Van Tongeren, D. R., Green, J. D., Davis, D. E., Hook, J. N., \& Hulsey, T. L. (2016). Prosociality enhances meaning in life. The Journal of Positive Psychology, 11(3), 225-236. https://doi.org/10.1080/17439760.2015.1048814

Zurqoni, Z., Retnawati, H., Apino, E., \& Anazifa, R. D. (2018a). Impact of character education implementation: A goalfree evaluation. Problems of Education in the 21st Century, 76(6), 881-899. https://doi.org/10.33225/pec/18.76.881

Zurqoni, R., Apino, E., \& Anazifa, R. D. (2018b). Impact of character education implementation: A goal-free evaluation. Problems of Education in the 21st Century, 76(6), 881-899. https://jsser.org/index.php/jsser/article/view/294Van der Geer, J., Hanraads, J. A. J., \& Lupton R. A. (2000). The art of writing a scientific article. Journal of Scientific Communications, 163, 51-59. 